\title{
Prey species and prey selection of dholes at three different sites in Thailand
}

\author{
KHWANRUTAI CHARASPET, RONGLARP SUKMASUANG״, NORASET KHOEWSREE, \\ MANANYA PLA-ARD, YUWALUK CHANACHAI \\ Forest Biology Department, Faculty of Forestry, Kasetsart University. 50 Phaholyothin Road, Chatuchak, Bangkok 10900, Thailand. \\ Tel. +66-257-90176 Fax. +66-294-28107, `email: mronglarp@ gmail.com
}

Manuscript received: 10 September 2020. Revision accepted: 17 October 2020.

\begin{abstract}
Charaspet K, Sukmasuang R, Khoewsree N, Pla-ard M, Chanachai Y. 2020. Prey species and prey selection of dholes at three different sites in Thailand. Biodiversitas 21: 5248-5262. The study of prey species and prey selection of Dholes at 3 different sites was conducted at Khao Yai National Park, Salak Pra, and Huai Kha Khaeng Wildlife Sanctuaries from 2013 to 2020. Information on Dhole prey at the sites was collected from the residues of dhole scats, from which the selection index, the relative biomass of the prey, and the relative amounts of the consumed prey were calculated. The data were collected simultaneously with the use of camera traps at each site. The study revealed that there were 13 species of Dhole prey with body weight over $5 \mathrm{~kg}$. The result indicated that there were $7 \mathrm{species}$ of even-toed ungulates. The relative biomass of even-toed ungulates ranged between $76.78-90.50 \%$ of the total biomass of all the Dholes' consumed prey for all study sites. The dietary diversity index unveiled a similar index in all areas, which proved the adequacy of the analyzed scats. However, the Niche breadth index, which indicates the relevance of prey selection and prey species to the appearances of the prey at each site, was found to be high at Huai Kha Khaeng Wildlife Sanctuary, Khao Yai National Park, while the index was found to be low at Salak Pra Wildlife Sanctuary. The results revealed that Dholes consumed viverrid species and Malayan porcupine more often at the site where there were large carnivores. The recommendation from this study was the conservation and restoration of the ungulate populations, the main prey, as it greatly affects the conservation of the Dhole populations in Thailand. Grassland and salt lick sites, water sources improvements are also important to promote prey population. The conservation of wildlife prey by releasing them to nature, as currently conducted, has an effect on the increase of Dholes' prey species.
\end{abstract}

Keywords: Dhole, Dong Phayayen-Khao Yai, Thungyai-Huai Kha Khaeng, Scat analysis, camera trap

\section{INTRODUCTION}

The study of the relationship between carnivores and their prey is important in order to understand the ecosystem. It allows us to understand the extinction of the carnivores (Tucker and Rogers 2014), which are mostly sensitive to environmental changes (Voigt et al. 2003; Karssene et al. 2017) mainly caused by human activities (Ripple et al. 2014). The carnivores' prey consumption is a natural selection process for acquiring as much food as possible in an inconstant environment, particularly the alteration in species and quantity of the prey living in each distribution site for those animals (Sunquist and Sunquist 1999). Dholes (Cuon alpinus Pallas, 1811) comprise one of the Canidae from the two species specifically found in Asia. There are less than 2,500 adult populations in nature (Srivathsa et al. 2014; Kamler et al. 2015; Wolf and Ripple 2017). The conservation status of Dhole is an Endangered species (Kamler et al. 2015). It is a wildlife species that is rarely being studied among wild dogs globally (Kamler et al. 2020; Srivathsa et al. 2020). Dhole is a medium-sized hyper carnivorous mammal (Van Valkenburgh 1991). It has an appropriate evolution for hunting and eating flesh, which is $70 \%$ of its diet (Johnsingh 1985). It has a close social connection in its pack caused by a close genetic bond. The pack members have communication ability: whistling, beholding, touching, hearing, and smell, so their high prey-hunting potential can be compared to the Tiger (Panthera tigris Linnaeus, 1758) and Leopard (P. pardus Linnaeus, 1758) (Bailey et al. 2013). Only a few wild dog species in this world hunt in packs (Marshall-Pescini and Kaminski 2014). Normally, there are 5-12 members in a Dhole pack (Johnsingh 1982; Durbin et al. 2004) to increase the efficiency in hunting large prey such as Banteng (Bos javanicus d'Alton, 1823), Gaur (Bos gaurus Smith, 1827), Sambar deer (Rusa unicolor Kerr, 1792), etc. These pack hunters have a great number of members and will need spacious areas for storing the prey, which is mainly ungulates, to appropriately maintain the Dhole populations in the ecosystem. Kamler et al. (2012) stated that the living area for long-term conservation of the Dhole populations is 5 times larger than for a tiger conservation site. Thus, in all distribution areas, the Dhole populations are rapidly decreasing due to the change of habitat environment and the decrease in their prey populations in the past decades (Wolf and Ripple 2016).

Study of the species and diversity of wildlife prey, mainly mammals can be studied using camera trapping. The use of non-invasive and standardized methods, camera traps, can provide data on presence, abundance of mammals, and their relationship with environmental factors. Despite the excellent results obtained with camera traps in inventories and analysis of richness and abundance of non-volant mammals (Voss and Emmons 1996; Trolle 
2003; Lyra-Jorge et al. 2008; Tobler et al. 2008). O'Brien (2008) stated that the next challenge for researchers will be the elaboration of projects about the potential use of camera traps in biodiversity monitoring. Many researchers state that the standardized method allows simple comparisons between sampling sites and inventories (Karanth and Nichols 1998; Silver et al. 2004; Kelly et al 2008; O’Brien 2008; Tobler et al. 2008).

A study of Dhole's prey selection beyond the study and the abundance of prey species in the area. It is necessary to study the prey species from the Dhole using scat analysis. Which was used mainly in this study. In general mammalian scats have been commonly used in biological studies to estimate population size (Kohn et al. 1999; Webbon et al. 2004) distribution patterns or species richness (Dalén et al. 2004), diet composition (Mahmood et al. 2011) as they are abundant and easily found (Sanz et al. 2007).

Fecal components of carnivores can comprise of feathers, bones, hairs, teeth, claws, scales, arthropod chitin, plant matter, mucus cells, and bacteria (Bujne 2000) whereas and size of carnivore scats can be different based on age of individuals, prey species consumed (Chame 2003). Scats can be used for animal identification (Seton 1925; Camardella et al. 2000), activity centers of animals and composition of diet (Santos and Hartz 1999; Kauhala and Auniola 2001), seasonal changes in diet (Aragona and Setz 2001), prey species inventory (Camardella et al. 2000), role in seed dispersal (Fragoso and Huffman 2000; Williams et al. 2000), animal health condition and enteroparasitosis dynamics (Page et al. 2001).

Prey species diversity of Dhole was studied within some protected areas of Thailand in the past. It realized that the prey species items differ, for example, Grassman et al. (2005) studied the prey species item in Phu Khieo Wildlife Sanctuary, Chaiyaphum Province, Thailand, and analyzed 172 scats. It was revealed that the majority of prey comprised Red muntjac (Muntiacus muntjak Zimmermann, 1780), Sambar deer, Wild boar (Sus scrofa Linnaeus, 1758), and Hog deer (Axis porcinus Zimmermann, 1780), respectively. Slansingh et al. (2007) reported that there were six prey species found from 33 scats in Phu Khieo Wildlife Sanctuary, which consisted of Sambar deer, Red Muntjac, Lesser Oriental Chevrotain (Tragurus kanchil Raffles, 1821) Hog deer, Hog badger (Arctonyx collaris (Cuvier, 1825)) and Burmese Striped Squirrel (Tamiops mcclellandii Horsfield, 1840), respectively. Prayoon (2014) revealed that there were nine species of prey in Thap Lan National Park, Prachinburi Province, found in 44 scats. According to the order of priority, those species were Wild boar, Lesser oriental chevrotain, Sambar deer, Red muntjac, Hog badger, snake, Siamese hare (Lepus peguensis Blyth, 1855), and bird, respectively. It shows that the Dholes' main prey in Thailand were the even-toed ungulates which give the same study result as the study in Laos (Kemler et al. 2012) and Khoewsree et al. (2020) in Khao Yai National Park, Thailand.
This study wants to know how many main prey species of Dhole in the study areas, what prey species are included? The next important question is, does the variety of prey types in each area affect the Dhole's prey eating? Is the electivity index of Dhole's stable? How does the overlap of prey between Dhole - Tigers and Leopards influence dhole prey eating? The tools used in the study were prey species identified by scat analysis. The abundance of prey studied using camera traps. Relative biomass consumed, number individual od prey consumed, electivity index. This study calculated the value of niche breadth index to consider a wide range of prey choices in each area. Niche breadth is an important parameter for the evaluation of the level of dietary specialization in a given group of species (Segurado et al. 2011). Species with niches of reduced breadth are relatively specialized, whereas more ample niches are typical of generalist species. The analysis of niche overlap also provides an important approach for the evaluation of the structuring of communities in terms of the feeding niches of the different species that compose them (Corrêa et al. 2011). The degree of specialization for the exploitation of specific types of resources could be used to classify groups of species in feeding guilds (Winemiller and Pianka 1990). This study also used the dietary diversity index to consider suitability is that sufficient amount of feces used in the study to be sufficient for the study? That had never been investigated in Thailand. The results will clarify the understanding of the species and the quantity of prey consumed by the Dholes in order to manage the living area for conserving this endangered species.

\section{MATERIALS AND METHODS}

\section{Study areas}

\section{Khao Yai National Park}

Khao Yai National Park (KYNP) is the first national park in Thailand located between $14^{\circ} 05^{\prime}-14^{\circ} 15^{\prime} \mathrm{N}$ latitude and $101^{\circ} 05^{\prime}-101^{\circ} 50^{\prime} \mathrm{E}$ longitude. It covers 2,168 $\mathrm{km}^{2}$ in the Phanom Dong Rak mountain range along the central and northeast region of Thailand. It is part of Dong Phayayen-Khao Yai, which was designated a world natural heritage site in 2005. It is the residence which collects varieties of living species: over 700 species of vertebrate, 112 species of mammal, over 392 species of bird, over 200 species of reptile and amphibian (IUCN 2020a). Most parts of the forest comprise dry evergreen forest, rainforest, hill evergreen forest, and little of grassland from the previous shifting cultivation (NPRD 2017). The study was conducted around the office of KYNP, which is located in the center area. The study area covers about $100 \mathrm{~km}^{2}$. The annual average rainfall in KYNP in a decade (2008-2017) is 1,897.07 mm (NPRD 2017). The highest rainfall is from May to October. September has the highest rainfall at $353.44 \mathrm{~mm}$. The average temperature throughout the year is $21.28^{\circ} \mathrm{C}$. The highest average temperature is $30.33^{\circ} \mathrm{C}$ in April, while the lowest average temperature is $12.25^{\circ} \mathrm{C}$ in January (NPRD 2017). 

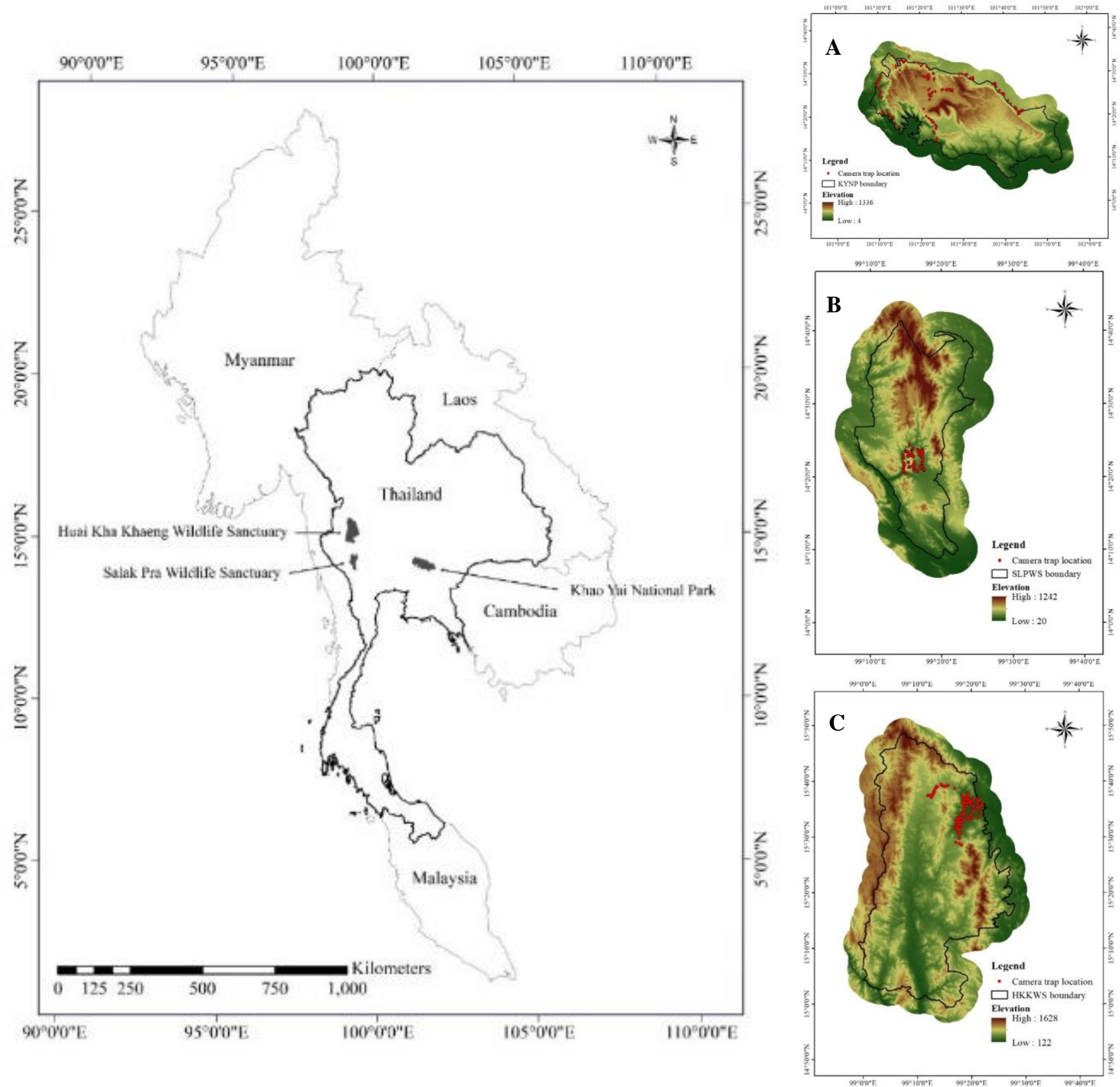

Figure 1.The locations of the study sites, including Khao Yai National Park in Nakhon Ratchasima, Salak Pra Wildlife Sanctuary in Kanchanaburi, and Huai Kha Khaeng Wildlife Sanctuary in Uthai Thani, Thailand. A-C. The locations of camera trap in each study sites, Khao Yai National Park (A), Salak Pra Wildlife Sanctuary (B), and Huai Kha Khaeng Wildlife Sanctuary (C), Thailand. (Department of Land Development 2016)

\section{Salak Pra Wildlife Sanctuary}

Salak Pra Wildlife Sanctuary (SPWS), Kanchanaburi Province, was announced as Thailand's first wildlife sanctuary in 1965. It is located in the east end of Tenasserim mountain range. It is between $14^{\circ} 9^{\prime}-14^{\circ} 40^{\prime}$ $\mathrm{N}$ latitude and $99^{\circ} 9^{\prime}-99^{\circ} 30^{\prime} \mathrm{E}$ longitude. It covers around $858.55 \mathrm{~km}^{2}$. Most parts of the forest are mixed deciduous forest, dry dipterocarp forest, and bamboo forest. It is a habitat with at least 352 wildlife species: 191 species of bird, at least 59 species of mammal, 39 species of reptile, 17 species of amphibian, at least 46 species of freshwater fish (Forest Biology Department 2013). The lowest average temperature throughout the year is $23.65^{\circ} \mathrm{C}$, while the lowest average temperature is $19.6^{\circ} \mathrm{C}$ in December. The highest average temperature is $38.2^{\circ} \mathrm{C}$ in April. The highest average temperature throughout the year is $34.25^{\circ} \mathrm{C}$. The annual average rainfall is $1,056.4 \mathrm{~mm}$. September has the highest rainfall, averaging 220.5 millimeters. January has the lowest rainfall, averaging $3.3 \mathrm{~mm}$ (Forest Biology Department 2013).

\section{Huai Kha Khaeng Wildlife Sanctuary}

Huai Kha Khaeng Wildlife Sanctuary (HKKWS), Uthai Thani Province, covers about $2,780 \mathrm{~km}^{2}$. It is between $15^{\circ}$ 
$15^{\prime}-15^{\circ} 45^{\prime} \mathrm{N}$ latitude and $99^{\circ} 5^{\prime}-99^{\circ} 25^{\prime} \mathrm{E}$ longitude. It is part of Thung Yai - Huai Kha Khaeng, a world natural heritage site. The area was announced as a world natural heritage site in 1990 as it collects a variety of plants and wildlife species resulting from the crossroad of 3 different zoogeographic regions (IUCN 2020b). Most parts of the area comprise dry dipterocarp forest, mixed deciduous forest, secondary forest, mixed deciduous forest, and dry evergreen forest (Forest Research Centre 1997). The annual temperatures in the HKKWS range between $8-38^{\circ} \mathrm{C}$ with the lowest temperature in January and the highest temperature in April. Average annual rainfall is 1,375 mm. The dry season is from November to April with average rainfall at $298 \mathrm{~mm}$, while the rainy season is from May to October with average rainfall at 1,088 millimeters )The Western Forest Complex Ecosystem Management Project 2003; Western Forest Complex 2004). HKKWS is known as a home for top carnivores including Tiger, Leopard, and Dhole and important herbivores including Gaur, Banteng, Sambar deer, Wild boar, and Red muntjac )Petdee 2000; The Western Forest Complex Ecosystem Management Project 2003; Simcharoen 2008). The locations of the three study sites are as well as camera trap locations of each study site are shown in Figure 1.

\section{Data collection \\ Camera trapping}

The abundance of Dholes and other mammalian species or prey were studied using camera trap by determining 1 square grid on a topographic map as 1:50,000. Each square grid was equal to $1 \mathrm{~km}^{2}$. One camera trap was installed in every one grid (Gupta et al. 2009; Jenks et al. 2011; 2012; Siripattaranukul et al. 2015). In all of the study sites, the cameras were set to take photos took a sequence of 3 photos within 10 seconds between consecutive events. The triggering speed of all the camera models was fairly similar.

A standard form was filled for each camera trap location, containing information about the date, GPS coordinates, serial number of the camera trap, team members setting up the cameras, habitat description. The camera traps, 10 - 15 sets of Bushnell 8MP Trophy Cam Standard Edition camera trap model were used in SPWS, 15 - 20 sets of Bushnell Trophy Cam Trail Camera, Essential E3 model were used in KYNP and HKKWS. The camera traps are activated by movement through a passive infrared beam, shooting a $35 \mathrm{~mm}$ analog camera. Sampling sites were $500 \mathrm{~km}$ away from each other at least in each 1 $\mathrm{km}$ square grid, and camera traps were set up at $0.4 \mathrm{~m}$ above the ground and perpendicular to the trails. The cameras were programmed to remain turned on $24 \mathrm{~h}$ a day. Camera traps remained in the field for 30 days and were removed to another point to cover more of the study area. GPS was used to record the cameras' positions. The initial material for the analysis was the resulting photographs in JPG format. The unloading, storage, sorting and initial processing of images were carried out with the help of Camera Trap Manager Programme (Zaragozí et al. 2015) and brought into Microsoft Excel for further data analysis. The main performance indicators for camera traps are standard for this kind of research (Mohd-Azlan and Sharma 2006; Kelly and Holub 2008; Rovero et al. 2010; 2014).

The cameras were set in KYNP during October 2017 September 2018, which were 72 locations, and 1,795 traps nights. The cameras were installed in SPWS from May 2013 to April 2014, which were 120 positions and 3,600 trap nights in total. The cameras were installed in HKKWS during November 2017 - February 2020, which were 192 positions and 6,596 trap nights in total.

\section{Collection and treatment of scats}

Dholes' scats were collected along forest surveillance pathways and wildlife trails randomly By trying not to collect Dholes' scats in the same pack each time. The scat collection was done at KYNP, SPWS, and HKKWS regularly every month, once a time for 8-12 kilometers throughout the year. Total distance for finding and collecting Dholes' scats in each area was 205, 178, and 240 $\mathrm{km}$, at KYNP, SPWS, and HKKWS respectively. A scat would be categorized from its looks, size, as well as the obvious animal tracks nearby (Cohen et al. 1978; Johnsingh 1992; Karanth and Sunquist 1995; Durbin et al. 2004; Thinley et al. 2011; Kamler et al. 2012). A scat found in a plastic bag was brought back and its details were recorded, there were geographic coordinates, forest habitat types, time, and date. The structure of hair was analyzed at the laboratory of Forest Biology Department, Kasetsart University using the Dhole scat to classify the prey species. This method is widely used to classify prey species of the carnivore, including the Dholes (Fox and Johnsingh 1975; Cohen et al. 1978; Johnsingh 1983; Phetdee 2000; Andheria et al. 2007; Acharya et al. 2007; Simchareon, 2008; Wang and MacDonald 2009; Arivazhagan et al. 2007; Edgaonkar 2008). Each scat was cleansed with fresh water. All types of animal hair found in the scats were picked up and washed with dishwashing liquid and detergent to get rid of grease. After that, an ultrasonic machine was used to shake the dirt off before packing them into a paper envelope to dry at $60^{\circ} \mathrm{C}$ for $24 \mathrm{~h}$.

To study the hair cuticle, acetone was used and mixed with clear nail polish before sweeping onto a slide sheet and allowed to dry. The hair was picked up and pressed on the sheet until the pattern of the cuticle appeared on the nail polish, after which it was brought out and checked with microscope followed by recording the patterns of the cuticle in the root, middle, and the end of the hair. The medulla was studied by soaking the hair in xylene for about $24 \mathrm{~h}$, checked with a microscope, and recorded the patterns of the medulla of the middle of the hair and all positions with different patterns. It was categorized by referring to the studied photographs of cuticle and medulla with the hair of mammals as described by Phetdee (2000) and Slangsingha (2013), together with studying other visible residues in the scat, such as hair colors, size of the hair, bones, teeth, and hoof.

\section{Data analysis \\ Relative abundance index (RAI)}

RAI was used in this study because the method was strong relationship between camera trap-derived RAI 
values and independently gathered density, indicating that the photographic captures can serve as a reliable index of relative abundance (Palmer et al. 2018). The photographically recorded mammalian species were classified and used as common names and scientific names according to Lekagul and McNeely (1988), only for the photographs which could be clearly categorized with date and time presented on the photographs. Over one mammalian species in the same photo is counted as one event (O'Brien et al. 2003) and it was independent. The criteria used to classify events or the independency of animal photographs were (1) the consecutive photographs of different individuals of the same or different species (2) the photographs of the individual of the same species taken more than $30 \mathrm{~min}$ apart (3) the non-consecutive photographs of the individual of the same species (O'Brien et al. 2003). These include the number of trap nights or camera days (TN) spent by one camera at i-th location; number of animal passes/registrations at i-th location; total number of pictures/frames for each species; the relative abundance index (RAI), which was calculated by formula:

$$
\mathrm{RAI}=\frac{\mathrm{N}(100)}{\mathrm{A}}
$$

When $\mathrm{N}$ is the number of independent photos or event where those individuals were found, multiplied by a hundred, and divided by A that is total trap night.

\section{Estimation of frequency of occurrence}

The information of the recorded prey species from the laboratory was used to calculate the frequency of occurrence $(\% \mathrm{FO})$ using the number of scats that prey species presented multiplied by 100 and divided by the total number of all scat detections.

\section{Correction factor}

The linear regression model $) y_{\mathrm{i}}=0.439+0.008 \mathrm{x}_{i}($ (Floyd et al. 1978; Weaver 1993) used to calculate biomass consumed of different prey species of Dhole (e.g. Andheria et al. 2007; Kamler et al. 2012 ( in the area. In the model, $x_{i}$ is the live body mass of prey, whereas yi is the mass of prey per collected scat $) i$.

\section{Relative biomass and number of prey species consumed}

The relative biomass (RBC) and a relative number of prey species consumed (RNC) were calculated as described by Andheria et al. (2007). The relative proportion of biomass consumed was calculated using formula as:

$$
D=\frac{(A \times Y)}{\sum(A \times Y)}
$$

This formula was computed using the relative frequency of occurrence (A) of a species and correction factor (Y) and depicted as a percentage value. The relative proportion of the number of prey individuals consumed was calculated using formula as:

$$
\mathrm{E}=(\mathrm{D} / \mathrm{X}) / \sum(\mathrm{D} / \mathrm{X})
$$

Where E was number of prey individuals consumed. The formula was calculated using the average unit weight of each prey species (X) and the relative proportion of biomass consumed (D) (Karanth and Sunquist, 1995). The average weights of different prey species were obtained from published literature (Prater 1971; Schaller 1977; Ackerman et al. 1984; Lekagul and McNeely 1988, Weaver 1993; Karanth and Sunquist 1995; Shrestha 1997; Koirala et al. 2012). Prey species $<5 \mathrm{~kg}$ body mass was excluded from our analyses according to Andheria et al. 2007 and Kamler et al. 2012.

\section{Electivity index}

To determine selectivity for specific mammal species by Dhole, we calculated Ivlev's electivity index $) E$ ( as modified by Jacobs )1974( as:

$$
\mathrm{E}=\frac{(r-p)}{(r+p)-2 r p}
$$

Where $\mathrm{E}$ is prey selectivity, $r$ is the proportion of a given prey species in the predator's diet )from percent frequency of occurrence( and $p$ is the proportional availability, or abundance, of the prey species in the study area to assess which prey species were selected $) 0<E \leq 1$ ( and which were avoided $)-1 \leq E<0$ (. We calculated $E$ values from data from both biomasses consumed and individuals consumed, to determine if both methods showed similar trends. For each prey species, the $E$-value depends on which other species are included in the calculation. Therefore, we calculated $E$-values only for ungulate species for which abundances were determined during prey surveys. $E$-values of rare species often are biased )e.g., detection in 1 scat might lead to an $E$-value of +1 , whereas no detection would lead an $E$-value of -1(. To determine biomass available for each ungulate species, we multiplied adult female body masses based on Lekagul and McNeely )1988( by abundance estimates.

\section{Dietary diversity index}

Adequacy of the sample size was determined by calculating a Brillouin index or dietary diversity index (Glen and Dickman 2006) according to the equation:

$$
\mathrm{H}_{\mathrm{b}}=\frac{\ln \left(\mathrm{N}_{i}\right)-\sum \mathrm{n}_{i}}{\mathrm{~N}_{\mathrm{i}}}
$$

Where $\mathrm{H}_{b}$ is the diversity of prey in the sample, $\mathrm{N}_{\mathrm{i}}$ is the total number of individual prey taxa in all samples, and $\mathrm{n}_{\mathrm{i}}$ is the number of individual prey taxa in the I th category (Brillouin 1956).

\section{Niche breadth index}

The niche breadth index has also been called niche width or niche size by ecologists. Niche breadth can be measured by observing the distribution of individual organisms within a set of resource states (Colwell and Futuyma 1971). The niche breadth of each species in each study site was based on Levin's standardized index (Levins 
1968), standardized by Hurlbert (1978). Thus, the larger values indicate the amplitude in the ecosystem reflected by the prey species consumed by Dholes. Represents a greater variety of food types, has greater ecological stability compared to areas with less niche breadth index. The formula is as followed:

$$
\mathrm{Bi}=\left[\frac{1}{n-1}\right]\left[\frac{1}{\sum_{j} P_{i j}^{2}}-1\right]
$$

Where; $\mathrm{Bi}=$ standardized index of niche breadth, $\mathrm{pi}=$ proportion of the diet of predator $i$ on prey $j$, and $n=$ total number of item (resources). Bi values vary from 0 (species consume a single item) to 1 (species exploits available items in equal proportion). Values of $\mathrm{Bi}$ are considered high when higher than 0.6 , moderate, when between 0.4 and 0.6 and low when below 0.4 (Novakowski et al. 2008). Based on the biomass of prey categories consumed, we calculated Levin's measure of niche breadth (B; Krebs 1989) on each site.

\section{Niche overlap index}

Analysis of niche overlap between the most common species was based on classical Pianka's index (Pianka 1973), which is derived from the composition of the diet (percentages) of the different species between dholes and other large carnivorous mammals, tiger and leopard in HKKWS. We used results from a concurrent diet study of Leopards and Tiger in HKKWS (Phetdee 2000; Simchareon 2008) to calculate the degree of dietary overlap between Dholes and the 2 large cats using Pianka's niche overlap index as:

$$
\frac{\sum_{i}^{n} P_{i j} P_{i k}}{\sqrt{\left(\sum_{i}^{n} P_{i j}^{2}\right)\left(\sum_{i}^{n} P_{i k}^{2}\right)}}
$$

Where $P_{i j}$ is the percentage of prey species i of predator $\mathrm{j}, P_{i k}$ is the percentage of prey species $\mathrm{i}$ of predator $\mathrm{k}$. Pianka's index varies between 0 (total separation) and 1 (total overlap). We chose this index to allow direct comparison of the degree of overlap in similar studies of carnivores conducted elsewhere in the world (Fedriani et al. 2000; Ray and Sunquist 2001; Jacomo et al. 2004).

\section{Statistical analysis}

We used Chi-square contingency tables to determine if there were differences in the diets between sites (Aryal et al. 2015; Kamler et al. 2020). To meet Chi-square requirements for sample sizes, we grouped prey categories as Sambar deer, Red muntjac, Wild boar, Lesser oriental chevrotain, whereas we used all prey categories. If a significant difference $(\mathrm{P}<0.05)$ occurred, then we used Fisher's exact tests to determine which individual prey items significantly differed between sites (Aryal et al. 2015; Kamler et al. 2020).

\section{RESULTS AND DISCUSSION}

\section{The abundances of dholes and prey species}

The 72 camera traps in KYNP set throughout the year for 1,795 trap nights, during October 2017 - September 2018 , resulted in 2,052 independent photographs. In total, there were 30 species of wild mammal, 19 species of wild carnivore mammals, and 11 species of wild herbivore mammals. The carnivores with the greatest number of photographs taken were Dholes with $1.11 \%$ of abundance. There were 12 species of wild herbivore mammals with the respective level of abundance as follows: Red muntjac (2.34\%), Sambar deer (2.28\%), Wild boar (1.95\%), Lesser Oriental Chevrotain (0.50\%), Malayan porcupine (Hystrix brachyura Linnaeus, 1758) (1.50\%). Otherwise, Macaque $(0.84 \%)$, Grey-bellied squirrel (Callosciurus caniceps Gray, 1842) (0.88\%), Finlayson's squirrel (Callosciurus finlaysonii Thomas Horsfield, 1823) (0.16\%), Serow (Capricornis sumatraensis Bechstein, 1799) (0.11\%), and Asiatic brush-tailed porcupine (Atherurus macrourus Linnaeus, 1758) $(0.06 \%)$ were also found.

In the case of the study at SPWS based on 120 camera trap locations for 3,600 trap nights, showed that Dhole was the most outstanding animal with 13.92 abundance index. Other large carnivores, i.e. Leopard, had a 0.28 abundance index. There were 17 species of other herbivore prey captured from the camera traps, i.e. Sambar deer (80.68), Red muntjac (23.93), Wild boar (8.76), Hog deer (3.99), etc.

In HKKWS the camera traps installed in 192 positions in the survey area for 6,596 trap nights resulted in 10,711 independent photographs. There were 39 species of wild mammal and 20 species of wild carnivore mammal. The camera took 242 photographs of Tigers, which was relative abundance (RAI) of 3.67\%, 637 photographs of Leopard, which was RAI of $9.66 \%$ percent of abundance, and 83 photographs of Dholes, which was RAI of $1.26 \%$.

The study results of the abundance of Dholes and the potential Dholes' wild prey, number of photographs, and the positions of cameras which captured the individuals are shown in Table 1. 
Table 1. The abundance of Dholes and prey species in KYNP as surveyed during October 2017-September 2018 in KYNP from 72 camera positions for 1,795 trap nights, in SPWS during May 2013-April 2014 from 120 camera trap positions for 3,600 trap nights and in HKKWS during November 2017 - February 2020, from 192 camera trap positions for 6,596 trap nights.

\begin{tabular}{|c|c|c|c|c|c|c|c|c|c|c|}
\hline \multirow{2}{*}{ Family, common name } & \multirow{2}{*}{ Scientific name } & \multicolumn{3}{|c|}{ Number of events recorded } & \multicolumn{3}{|c|}{ Number of locations found $(\%)$} & \multicolumn{3}{|c|}{$\%$ RAI } \\
\hline & & KYNP & SPWS & HKKWS & KYNP & SPWS & HKKWS & KYNP & SPWS & HKKWS \\
\hline \multicolumn{11}{|l|}{ Canidae } \\
\hline Dhole & Cuon alpinus & 133 & 61 & 83 & $20(27.78)$ & $14(11.67)$ & $41(21.35)$ & 1.11 & 2.06 & 1.26 \\
\hline \multicolumn{11}{|l|}{ Cervidae } \\
\hline Sambar deer & Rusa unicolor & 394 & 2,384 & 2,189 & $41(56.94)$ & $47(39.17)$ & $142(73.96)$ & 2.28 & 80.68 & 33.19 \\
\hline Red muntjac & Muntiacus muntjak & 127 & 707 & 907 & $42(58.33)$ & $55(45.83)$ & $122(63.54)$ & 2.34 & 23.93 & 13.75 \\
\hline \multicolumn{11}{|l|}{ Suidae } \\
\hline Wild boar & Sus scrofa & 396 & 259 & 718 & $35(48.66)$ & $63(52.50)$ & $137(71.35)$ & 1.95 & 8.76 & 10.89 \\
\hline \multicolumn{11}{|l|}{ Tragulidae } \\
\hline Lesser Oriental Chevrotain & Tragulus kanchil & 17 & - & - & $9(12.50)$ & - & - & 0.50 & - & - \\
\hline \multicolumn{11}{|l|}{ Bovidae } \\
\hline Banteng & Bos javanicus & - & - & 467 & - & - & $86(44.79)$ & - & - & 7.08 \\
\hline Gaur & Bos gaurus & - & - & 45 & - & - & $15(7.81)$ & - & - & 0.68 \\
\hline Serow & Capricornis sumatraensis & - & - & 2 & - & - & $2(1.04)$ & - & - & 0.03 \\
\hline \multicolumn{11}{|l|}{ Viverridae } \\
\hline Large Indian civet & Viverra zibetha & - & 12 & 862 & - & $5(4.17)$ & $104(2.08)$ & - & 0.41 & 13.07 \\
\hline Asian palm civet & Paradoxurus hermaphroditus & 24 & - & 526 & $15(20.83)$ & - & $68(35.41)$ & 0.84 & - & 7.97 \\
\hline Masked palm civet & Paguma larvata & - & - & 23 & - & - & $14(7.29)$ & - & - & 0.35 \\
\hline Small Indian civet & Viverricula indica & - & 2 & 23 & - & $2(1.67$ & $16(8.33)$ & - & 0.07 & 0.35 \\
\hline Large-spotted civet & Viverra megaspila & 51 & 12 & 8 & $9(12.50)$ & $8(6.67)$ & $6(3.12)$ & 0.50 & 0.41 & 0.12 \\
\hline Common palm civet & Paradoxurus hermaphroditus & - & 8 & - & - & $7(5.83)$ & - & - & 0.27 & - \\
\hline \multicolumn{11}{|l|}{ Hystricidae } \\
\hline Malayan porcupine & Hystrix brachyura & 129 & - & 803 & $27(37.50)$ & - & $119(61.98)$ & 1.50 & - & 12.17 \\
\hline
\end{tabular}




\section{Prey species trom scat}

The analysis of the 276 scats of Dhole in KYNP from January 2017 to March 2020 could classify 9 species of the large prey that weighed over 5 kilograms and were used for calculation. They included Sambar deer, Red muntjac, Wild boar, Masked palm civet (Paguma larvata C. E. H. Smith, 1837), Asian palm civet (Paradoxurus hermaphroditus Pallas, 1777), Large Indian civet (Viverra zibetha Linnaeus, 1758), Lesser oriental chevrotain, Malayan porcupine (Hystrix brachyura Linnaeus, 1758), and Binturong (Arctictis binturong Raffles, 1821). It was unveiled that only one specific prey species was found in each of 167 scats $(60.72 \%)$, two prey species were found in each of 96 scats $(34.90 \%)$, and three species were found in each of 13 scats $(4.72 \%)$. The calculation of percentage frequency of occurrence $(\% \mathrm{FO})$ of the species found in the scats in a year showed that animals with the highest percentage of frequency of occurrence were Sambar deer (43.84\%), Red muntjac (36.95\%), and Wild boar (16.30\%) and so on respectively, as shown in Table 2.

From the analysis of 175 Dhole scats found at SPWS, 6 species of large prey were found. They were Wild boar, Large Indian civet, Sambar deer, Red muntjac, and Lesser oriental chevrotain. Even though it couldn't have been captured by the camera trap at the site before, this study found that Lesser oriental chevrotain had become the prey. The calculation of percentage frequency of occurrence $(\% \mathrm{FO})$ of the species found in the scats showed that animals with the highest percentage of FO were Wild boar (53.71\%), Large Indian civet )23.43\%(, Sambar deer $(10.29 \%)$, Red muntjac $(8.57 \%)$, and Lesser oriental chevrotain $(1.71 \%)$, respectively, as shown in Table 2.

In HKKWS, the study of prey species revealed that, from 44 scats, only one specific prey species was found in each of 32 scats $(72.72 \%)$, two prey species were found in each of 10 scats $(22.72 \%)$, and three species were found in each of 2 scats $(4.54 \%)$. Seven species of ungulate had become the prey. They were Sambar deer, Wild boar, Red muntjac, Lesser oriental chevrotain, and Gaur. The highest relative biomass of prey consumed was Red muntjac $(37.31 \%)$, Sambar deer $(26.30 \%)$, Gaur $(5.66 \%)$, Lesser oriental chevrotain $(2.78 \%)$ respectively. By considering the percentage of the relative number of prey individual consumed by dholes in SPWS, the percentage of a prey individual consumed at the site were Red muntjac (19.57\%), Lesser oriental chevrotain (9.97\%), Sambar deer $(1.39 \%)$ as shown in Table 2.

\section{Prey biomass consumed}

The highest relative biomass values for prey consumed in KYNP were Sambar deer (58.67\%), Wild boar $(15.13 \%)$, and Red muntjac $(14.03 \%)$. The smaller-sized prey samples were Asian palm civet, Masked palm civet, Large Indian civet, Lesser oriental chevrotain, Binturong, and Malayan porcupine. Most of the prey comprised ungulates species $(88.65 \%)$, so they became the main prey. By considering the percentage of the relative number of prey individual consumed by Dhole in a year, the highest percentage of prey consumed were viverrid species (64\%), ungulates species (2Y.J\%), rorcupine species (כ.2כ\%), Binturong species (1.25\%), and other animals.

To understand prey species, the analysis of the 175 scats of Dhole in SPWS in a year unveiled that only one specific prey species was found in each of 150 scats $(85.71 \%)$, two prey species were found in each of 22 scats $(12.57 \%)$, and three species were found in each of 3 scats $(1.72 \%)$. Five species of ungulate had become the prey. They were Sambar deer, Wild boar, Red muntjac, Lesser oriental chevrotain. The highest relative biomass of prey consumed comprised Wild boar (65.81\%), Sambar deer $(18.17 \%)$, Red muntjac $(4.30 \%)$, and Lesser oriental chevrotain $(0.64 \%)$, respectively. By considering the percentage of the relative number of prey individual consumed by Dholes, the percentage of prey consumed were Wild boar $(23.07 \%)$, Red muntjac (8.65\%). The majority of the consumed animals were Viverrid species (53.84\%) (Table 2).

Comparing the relative prey biomass consumed by Dhole of the even-toe ungulate species in the 3 study areas found that in SPWS has the highest $(90.50 \%)$ followed by KYNP (88.65\%) and HKKWS (76.78\%), respectively. Comparing the relative biomass percentage for even-toed ungulate species of this study with those in other areas in India, it was found that obtained from this study was slightly less, as shown in Table 3. This study also included Hog deer and Eld's deer, that reintroduced into the nature of the area that consumed by the Dholes to show prey species items but Hog deer and Eld's deer did not include in electivity index calculation due to both of the species were reintroduced animal that distributed in limited of the area.

\section{Prey election index}

The election index of the even-toed ungulates prey in KYNP indicated that the Dholes consumed Sambar deer (0.02), Wild boar (0.01), Red muntjac (-0.04), and Lesser oriental chevrotain $(-0.55)$, while the election index in SPWS indicated the dhole consumed Sambar deer (0.02), Red muntjac (0.12), Lesser oriental chevrotain (1.00(, and Wild boar (-0.05). The election index in HKKWS indicated that the dholes consumed Sambar deer (0.004(, Red muntjac (-0.02(, and Lesser oriental chevrotain (1.17).

Considering the average prey electivity index of Dhole on the even-toe ungulate species in all study areas found that the Dhole likes to select to Lesser Oriental Chevrotain the most followed by Red muntjac, Sambar deer and Wild boars respectively as shown in Figure 2.

The difference of relative biomass of prey between the sites

The biomass of prey in the study sites was generally considered according to taxa to test Chi-square. It was unveiled that the biomasses of prey in association with the information of prey species, i.e. ungulate species and viverrid species, were not different in all 3 sites: KYNP and SPWS $\left(x^{2}=0.07, \mathrm{P}=0.791\right)$; KYNP and HKKWS $\left(x^{2}=0.096, \mathrm{P}=0.757\right)$; SPWS and HKKWS $\left(x^{2}=0.128, \mathrm{P}\right.$ $=0.721$ ). 
Table 2. Prey species, correction factor, percentage frequency of occurrence (\%FO), relative biomass consumed and relative number individual consumed by Dholes based on 276 Dholes' scat in KYNP, during January 2017 and January 2020., 175 Dholes' scats in SPWS, during May 2013 and April 2014, and 44 Dholes' scats in HKKWS during November 2018 and February 2019

\begin{tabular}{|c|c|c|c|c|c|c|c|c|c|c|c|}
\hline \multirow{2}{*}{ Common name } & \multirow{2}{*}{ Scientific name } & \multirow{2}{*}{$\begin{array}{l}\text { Correction } \\
\text { factor }^{1)}\end{array}$} & \multicolumn{3}{|c|}{$\% \mathrm{FO}^{2)}$} & \multicolumn{3}{|c|}{$\% \mathrm{RBC}^{3)}$} & \multicolumn{3}{|c|}{$\% \mathrm{RNC}^{4)}$} \\
\hline & & & KYNP & SPWS & HKKWS & KYNP & SPWS & HKKWS & KYNP & SPWS & HKKWS \\
\hline \multicolumn{12}{|l|}{ Cervidae } \\
\hline Sambar deer & Cervus unicolor & 2.22 & 43.84 & 10.29 & 9.09 & 58.67 & 18.17 & 26.3 & 6.50 & 3.85 & 1.39 \\
\hline Red muntjac & Muntiacus muntjak & 0.63 & 36.95 & 8.57 & 45.45 & 14.03 & 4.30 & 37.31 & 14.5 & 8.65 & 19.57 \\
\hline Hog deer & Axis porcinus & 0.12 & - & 16.57 & 15.9 & - & 1.58 & 2.49 & - & 1.92 & 0.76 \\
\hline Eld's deer & Panolia eldii & 0.76 & - & - & 2.27 & - & - & 2.24 & - & - & 0.25 \\
\hline \multicolumn{12}{|l|}{ Tragulidae } \\
\hline Lesser Oriental Chevrotain & Tragulus kanchil & 0.47 & 2.89 & 1.71 & 4.54 & 0.82 & 0.64 & 2.78 & 5.75 & 8.65 & 9.97 \\
\hline \multicolumn{12}{|l|}{ Suidae } \\
\hline Wild boar & Sus crofa & 1.54 & 16.30 & 53.71 & - & 15.13 & 65.81 & - & 2.75 & 23.07 & - \\
\hline \multicolumn{12}{|l|}{ Bovidae } \\
\hline Gaur & Bos gaurus & 1.91 & - & - & 2.27 & - & - & 5.66 & - & - & 0.12 \\
\hline \multicolumn{12}{|l|}{ Viverridae } \\
\hline Large Indian civet & Viverra zibetha & 0.51 & 7.27 & 23.43 & 6.81 & 2.24 & 9.50 & 4.52 & 6.50 & 53.84 & 6.69 \\
\hline Asian palm civet & Paradoxurus hermaphroditus & 0.47 & 19.57 & - & 9.09 & 5.55 & - & 5.57 & 39.75 & - & 20.08 \\
\hline Masked palm civet & Paguma larvata & 0.47 & 8.70 & - & - & 2.47 & - & - & 17.75 & - & - \\
\hline \multicolumn{12}{|l|}{ Mustelidae } \\
\hline Binturong & Arctictis binturong & 0.56 & 0.01 & - & - & 0.67 & - & - & 1.25 & - & - \\
\hline \multicolumn{12}{|l|}{ Hystricidae } \\
\hline Malayan porcupine & Hystrix brachyura & 0.49 & 1.44 & - & 6.81 & 0.42 & - & 4.35 & 5.25 & - & 27.4 \\
\hline \multicolumn{12}{|l|}{ Cercopithecidae } \\
\hline Phayre's langur & $\begin{array}{l}\text { Trachypithecus phayrei } \\
\text { Niche breadth Index (B) }\end{array}$ & 0.37 & - & - & 18.18 & $\begin{array}{c}- \\
0.753 \\
\end{array}$ & $\begin{array}{c}- \\
0.589 \\
\end{array}$ & $\begin{array}{c}8.77 \\
0.789 \\
\end{array}$ & - & - & 13.76 \\
\hline
\end{tabular}

individual consumed 
Table 3. Percentage of relative biomass of even-toed ungulate consumed in KYNP, SPWS, and HKKWS compared to the results in other research sites

\begin{tabular}{|c|c|c|c|c|c|c|c|}
\hline Prey species & KYNP *) & SPWS *) & HKKWS*) & 1) & 2) & 3) & 4) \\
\hline Sambar deer & 58.67 & 18.17 & 26.3 & 38.7 & 13.08 & - & 38.10 \\
\hline Wild boar & 15.13 & 65.81 & - & 11.12 & 4.48 & 28.00 & 0.35 \\
\hline Red muntjac & 14.03 & 4.3 & 37.31 & 1.23 & 0.99 & 45.20 & 0 \\
\hline Lesser oriental chevrotain & 0.82 & 0.64 & 2.78 & 1.11 & 0.08 & - & 0.90 \\
\hline Gaur & - & - & 5.66 & 10.24 & 0.87 & - & 4.10 \\
\hline Banteng & - & - & - & - & - & 19.20 & 0 \\
\hline Hog deer & - & 1.58 & 2.49 & - & 0 & - & 0 \\
\hline Eld's deer & - & - & 2.24 & - & 0 & - & 0 \\
\hline Chital & - & - & - & 1.40 & 78.26 & - & 53.75 \\
\hline Nilgiri Tahr & - & - & - & 1.85 & 0 & - & 0 \\
\hline Cattle livestock & - & - & - & 30.91 & 0 & - & 0 \\
\hline Four-horn antelope & & & & & 2.13 & - & 0 \\
\hline Total & 88.65 & 90.5 & 76.78 & 96.56 & 99.89 & 92.40 & 97.20 \\
\hline
\end{tabular}

Note: *) This study, 1) Kalakad-Mundanthurai Tiger Reserve, Tamil Nadu (Selvan et al. 2013), 2) Bandipur Tiger Reserve, India (Andheria et al. 2007), 3) Nam Et-Phou Louey, Laos and Srepok Wildlife Sanctuary, Cambodia (Kamler et al. 2020), 4) Mudumalai Tiger Reserve, Tamil Nadu, India (Ramesh 2010)

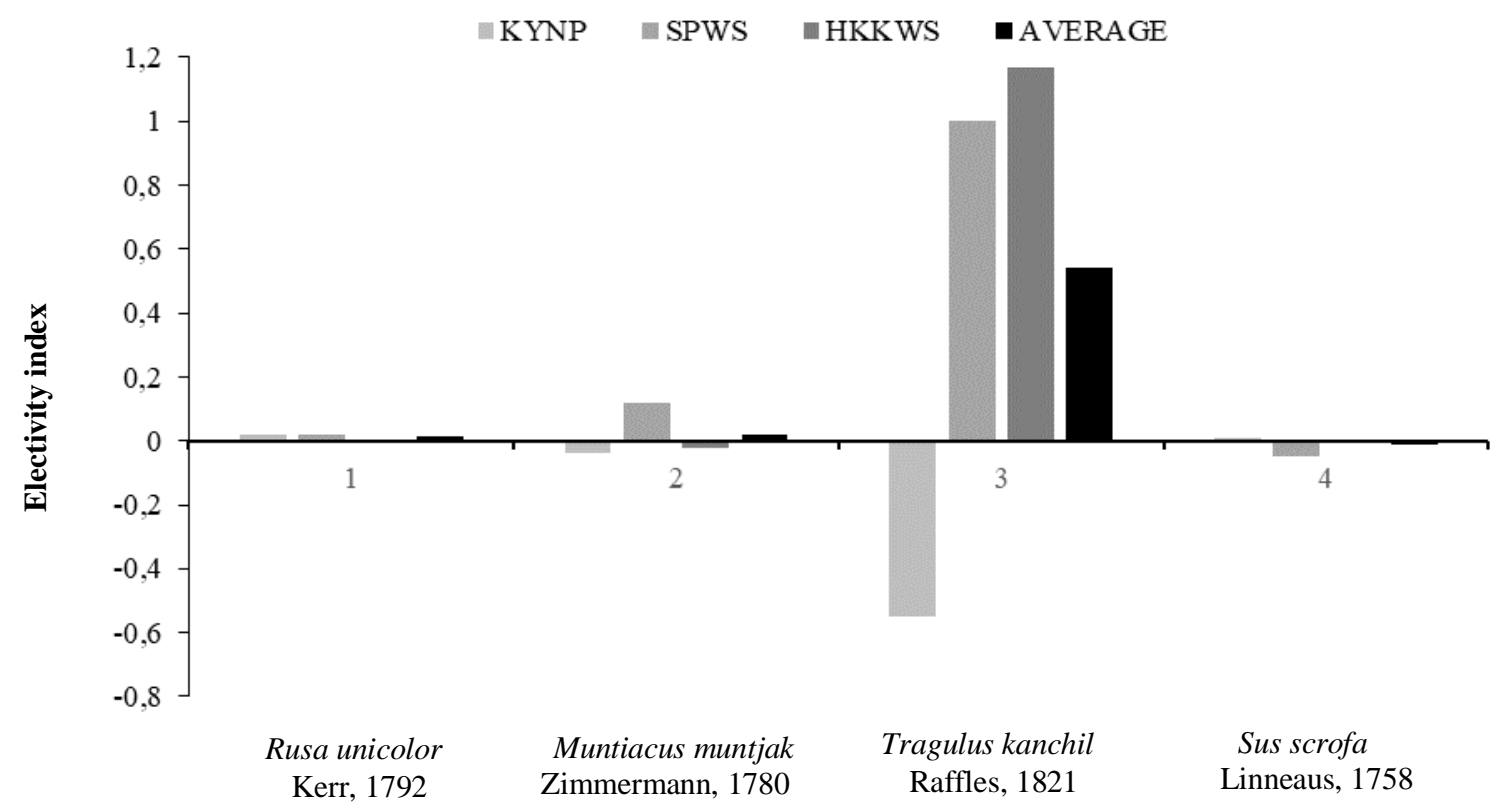

Figure 2. Shows Jacobs' (1974) electivity index (E) for Dholes' prey based on the percentage of relative biomass consumed in KYNP, SPWS and HKKWS, Thailand

\section{Dietary diversity index, Niche breadth index and Pianka prey overlap index}

A Dietary diversity index is the qualitative measurement of dietary or prey hunting of Dholes which reflects the access to diverse food in the ecosystem. The index is similar at the three sites. The highest dietary diversity index was found at HKKWS (4.4785), SPWS (4.4705), and KYNP (4.4288), respectively. It signifies that the adequacy number of scats of all sites used for the analysis to understand prey species is appropriate.

The study found the diverse prey species consumed by Dholes judging from the frequency of occurrence studied from the scat in each site. Niche breadth index shows the level of similarity between the frequencies of prey species consumed found in scats in each site and frequency distribution of prey in each site. The results from each site were similar. The highest index was found in HKKWS (0.789), KYNP (0.753), and SPWS (0.589), respectively.

Pianka's prey overlap index of Dhole $(n=44)$ and Leopard $(n=367)$ was 0.57 , while the overlap index of dhole and Tiger $(n=257)$ was 0.60 . The overlap index between Leopard and Tiger was 0.90 when using the results of prey species found in Leopard scats from the study of Simchareon (2008) and research results of prey species of tiger from the study of Phetdee (2000). However, Charaspet et al. (2019) reported that the overlap index between prey of Dhole and Leopard found between data collection process in HKKWS was 0.98. The overlap index between Dhole and Tiger was 0.68 which was higher than the result of this study. This could result from the 
different data collection time periods compared to the studies of Phetdee (2000) and Simchareon (2008), as well as the different numbers of samples, as shown in Table 7.

\section{Discussion}

Prey species

In the case of number of prey species of Dhole 13 prey species totally of this study, that is correspondent with the studies in Laos and Cambodia which reported that there were 10 prey species of Dhole in nature )Kamler et al. 2020). Selvan et al. 2013 reported that 11 species of prey totally were found in Kalakad-Mundanthurai Tiger Reserve, Tamil Nadu, India. It was the highest number of species found compared to seven other study results in conservation areas in the Indian subcontinent )Ramesh et al. 2012; Antheria et al. 2007; Karanth and Sunquist 1995; Acharya 2007; Borah et al. 2009; and Wang 2008) which reflects the quality of the habitat found in this research. It was revealed that the main prey was the even-toed ungulates which were Sambar deer, Wild boar, Red muntjac, and Lesser oriental chevrotain. Hog deer and Eld's deer, the reintroduced animals in HKKWS and SPWS, were also the prey of Dholes. However, in this study, Hog deer and Eld's deer have not included to analyze the electivity index. Since both species are released wildlife, they are distributed in a limited area. Although the study of Dholes' prey species found 14 prey species totally in the 3 study areas excluding small mammals, reptiles. However, Hayward et al. (2014) reported the types of food consumed by Dholes at 16 sites. It was unveiled from the study review that there were 35 species of prey; Sambar deer, Chital, and Wild boar were almost two-thirds of all biomass of prey consumed which corresponds to this study.

\section{Relative biomass consumed}

This study found that they were Sambar deer, Wild boar, Red muntjac, and Lesser oriental chevrotain are main prey of Dholes by considering the mean score consistent with the study results of Andheria et al. (2007) and Hayward et al. (2006; 2012; 2014) who reported that Sambar deer are the most important prey for the conservation of large carnivorous wildlife in Asia. The relative biomass consumed of Viverrid species and Malayan porcupine consumed by Dhole has the highest value in the HKKWS that points out avoid overlapping of Dholes' prey with tigers and leopards to hunt smaller prey. The result also found that when the prey species increased $(r=0.96)$ following the higher numbers of wildlife species at the site, based on camera trap data. The difference testing for wildlife prey at the three sites showed no statistical differences, consistent with the fact that Dholes consume the prey of wildlife in a similar amount regardless of sites, though depending on the appearance of prey and competitors in the ecosystem. In addition, the study results indicated that Hog deer and Eld's deer were the prey of dholes in HKKWS, while Dholes consumed Hog deer in SPWS. Hog deer and Eld's deer found in both sites were released from the project which had been conducted since 2008 to the present, which may affect the prey selection of dholes.
Table 7 Dietary diversity index, niche breadth index and Pianka's prey overlap index between Dholes and large carnivorous mammal species in KYNP, SPWS and HKKWS, Thailand

\begin{tabular}{|c|c|c|c|c|}
\hline \multirow{2}{*}{$\begin{array}{l}\text { Study } \\
\text { sites }\end{array}$} & \multirow{2}{*}{$\begin{array}{c}\text { Dietary } \\
\text { diversity } \\
\text { index }{ }^{1)}\end{array}$} & \multirow{2}{*}{$\begin{array}{c}\text { Niche } \\
\text { breadth } \\
\text { index }\end{array}$} & \multicolumn{2}{|c|}{$\begin{array}{c}\text { Pianka's prey overlap } \\
\text { index }\end{array}$} \\
\hline & & & Tiger $^{4)}$ & Leopard $^{5)}$ \\
\hline KYNP & 4.429 & 0.753 & NA & NA \\
\hline SPWS & 4.471 & 0.589 & NA & NA \\
\hline HKKWS & 4.479 & 0.789 & 0.600 & 0.570 \\
\hline
\end{tabular}

Note: 1) Based on the relative number of individuals consumed by dholes, 2) Based on the frequency of occurrence of prey species presented in dhole scats, 3) Based on the frequency of occurrence of prey species presented in dhole scats, 4) Based on Phetdee (2000), 5) Based on Simchareon (2008)

Hayward et al. (2014) reported that Sambar deer were an extremely important prey species for conserving the population of big carnivores and also Red muntjac in Southeast Asia (Kamler et al. 2020). It was also found that Wild boar had less importance for Dhole prey hunting (Selvan et al. 2013; Hayward et al. 2014), so it rationally explained the index which indicated the low preference for Wild boar of Dhole in SPWS. It was more difficult for Dholes to hunt Wild boar compared to Sambar deer, Red muntjac, or Eld's deer and Hog deer due to the Wild boar's fang that used for protecting itself from the hunt thus Dhole avoid to hunt Wild boar. Moreover, Wild boars, its heavy bodyweight, and short figure that is very difficult to hunt by Dhole. Although the highest biomass consumed by Dholes in SPWS belonged to Wild boar, the preference index was low. The Niche breadth index of SPWS was also the lowest. This indicated that the appropriateness of the habitat in SPWS for Dholes was lower than those of HKKWS and KYNP. Therefore, the restoration of ungulate populations and the protection management for the habitats in various dimensions were necessary for conservation.

\section{Electivity index}

Our study found that Red muntjac and Lesser oriental chevrotain were selected more than Sambar deer although the electivity indexes of Sambar deer consumed of the 3 sites were somewhat similar. This conforms to the report of Selvan et al. (2013). The indexes of even-toed ungulate consumed were varied in each site. The electivity indexes of Lesser oriental chevrotain consumed in SPWS and HKKWS were similar. They showed that Dholes preferably consumed Lesser oriental chevrotain. The study results for prey consumption of Dholes were consistent with the study results for all sites.

In case of Wild boar, there was a slight difference in KYNP and SPWS but in HKKWS, it is not found that Wild boar in the Dholes' scats. This is not to say that Wild boars are not important prey species. They are clearly killed frequently by dholes(Selvan et al. 2013; Hayward et al. 2014) but rather that they are killed less frequently than expected based on their relative abundance within the prey community (Hayward et al. 2014). Determined the overall the ungulates were found the main prey consumed, there were some differences in the details of the ungulate species consumed. Kamler et al. $(2012 ; 2020)$ reported that Red muntjac was the main prey, including in other countries in 
Southeast Asia which was the habitat of the Dholes followed by Sambar deer, Wild boar, and Serow, respectively. This finding corresponds with the study in HKKWS which found that Red muntjac was the main prey of Dholes. The absence of Wild boar in any scats found in HKKWS is also consistent with the study of Kamler et al. (2012; 2020) which reported that Dholes avoided consuming Wild boar by considering prey electivity index.

\section{Prey overlap index}

Charaspet et al. (2019) reported that Pianka's prey overlap index for Dhole and Leopard received from data collection in HKKWS pointed out the fierce competition in the area. That makes Dholes in the area it is less abundant than Tigers and Leopards and consumed smaller prey in Viverrid species and Malayan porcupines. That corresponds to Odden et al. 2010 who reported that where the dietary niches of sympatric competitors are identical, the species that can survive at the lowest resource density will outcompete and exclude the other. Preying on the same species increases the level of competition; but the ability to hunt a wider variety of prey may allow for dietary niche partitioning, and reduce the risk of encounters between carnivores (Karanth and Sunquist, 1995; Andheria et al., 2007).

\section{Dietary diversity index and Niche breadth index}

Dietary diversity index calculated from the relative number of prey species consumed was the qualitative measurement of the consumption or prey hunting which signifies the access of the Dholes to diverse food in the ecosystem. The results were somewhat similar in 3 sites. It indicated that the analyzed scats were adequate )Glen and Dickman 2006).

The study found that Niche breadth index (Bi) calculated from the relative biomass of prey consumed showed the level of similarity between the frequencies of prey species consumed found in scats in each site and frequency distribution of prey in each site. The index was 0.789 in HKKWS, 0.753 in KYNP, and 0.589 in SPWS. They were in the highest, high, and average levels, respectively )Novakowski et al. 2008). Determined Niche breadth index that represents the wide range of prey species that the Dholes consumed found to be high in the Huai Kha Khaeng Wildlife Sanctuary. This represents the diversity of Dholes' prey species found in the area that there are more than others to avoid the overlap of ungulate prey species with Tigers and Leopards.

\section{Difference of habitat}

By considering the forest in KYNP which is dry evergreen forest mixed with grassland resulted from the management, it was found that even-toed ungulates consumed by Dholes were Sambar deer, Wild boar, Red muntjac, and Lesser oriental chevrotain, respectively. Meanwhile, the main prey species were Wild boar, Sambar deer, Red muntjac, and Lesser oriental chevrotain in the mixed deciduous forest of SPWS. In HKKWS, Red muntjac, Sambar deer, Gaur, Lesser oriental chevrotain, were the ungulates mostly consumed. Kawanishi and
Sunquist (2008); Kamler et al. )2020( said that the different conditions of the sites affected prey selection. Generally, Dholes living in the overgrown forest tend to select small prey and catch bigger prey when living in a more open site, such as in India )Selvan et al. 2013). However, this study found that animal mostly consumed was Sambar deer in KYNP, Wild boar in SPWS, and Red muntjac in HKKWS. Lesser oriental chevrotain was also mostly consumed in HKKWS. As being managed to have an open habitat, Dholes in KYNP and SPWS could be hunted in the open areas and consumed large prey, such as Sambar deer, or Wild boar. The human-made open habitats were not found in the study site of HKKWS. These confirm that improvement of grassland habitat is important for species conservation.

\section{Recommendation}

The even-toe ungulate species should be the target for restoring the prey populations at the sites for conserving Dholes and the ecosystem. The restoration of prey populations by releasing them into nature in SPWS and HKKWS is a project that has been conducted by the Department of National Parks Wildlife and Plant Conservation since 2008 up to now. It produces good outcomes when considering the appearance of prey species. The study sites comprised conservation sites that have no threaten factors such as poaching, trespassing, or the release of livestock to the sites, which are part of the world's natural heritage. However, the problems of poaching, releasing livestock into the site, and doing human activities are still continuing at other conservation sites (Buabudhara 2019). Management for the preservation of Dhole should consider a large area rather than determined only in any conservation area especially in the forest complexes located in the east, north, and northeast regions of Thailand where Dhole still existing. Long term monitoring of the population of Dhole, their prey, and their interaction should be continued.

In conclusion, studies of species, the abundance of prey selection, relative biomass of prey, and the relative number of prey species consumed were conducted in KYNP, SPWS, and HKKWS, which have different conditions in the areas. Camera traps and scat analysis were used to understand the species and abundance of prey. It was revealed that the prey ( $>5 \mathrm{~kg}$ body weight) of Dholes comprised 13 species; nine species were found in KYNP, while six species were found in SPWS, and ten species were found in HKKWS. The results confirmed that the main prey of Dholes were ungulate species with relative biomass percentages at $88.65 \%, 90.50 \%$, and $76.78 \%$ in KYNP, SPWS, and HKKWS, respectively. Pianka's prey overlap index between Dhole, Tiger, and Leopard in HKKWS were 0.60 and 0.57 , respectively. It was found that the Dholes at the site consumed less even-toed ungulates and consumed other wild animals more in comparison with the other sites due to the competition between Dhole and large carnivore species, Tiger and Leopard. However, as found in KYNP and SPWS, where Dholes are the only dominant large carnivore, it mainly consumed the even-toed ungulates. The Niche breadth 
index was the highest in HKKWS. It represents the outcome of the complicated change of elements and the distribution of prey in the ecosystem of carnivores and various species of prey. The indexes were low at SPWS according to the criteria. Dietary diversity index indicated the adequacy of the number of scats for analysis as the numbers were considerably similar for all sites.

\section{ACKNOWLEDGEMENTS}

We would like to express our sincere thanks to the Centre for Advanced Studies in Tropical Natural Resources (CASTNaR), Kasetsart University in Bangkok, Thailand for providing financial support. We would also like to acknowledge the Earthwatch Institute USA for its fellowship and the financial support provided for Dhole research at Khao Yai National Park and Huai Kha Khaeng Wildlife Sanctuary. We would likewise like to show our appreciation to the volunteers of Earthwatch for their help in collecting data from scats, both at Khao Yai National Park and Huai Kha Khaeng Wildlife Sanctuary. We would like to express our recognition to the Unit for Capital Development for Human Resource Development, Capital for Higher Education Development, Research, and Innovation Creation, Office of National Higher Education Science Research and Innovation Policy Council (NXPO) under the research project on the ecology of important wildlife in Khao Yai National Park. We would like to express our gratitude to the Dean of the Faculty of Forestry for his constant support.

\section{REFERENCES}

Acharya. 2007. The Ecology of the Dhole or Asiatic Wild Dog (Cuon alpinus) in Pench Tiger Reserve, Madhya Pradesh. [Dissertation]. Wildlife Institute of India, Dehradun, India.

Ackerman BB, Lindzey FG, Hemker TP. 1984. Cougar food habits in southern Utah. J Wildl Manage 48: 147-155.

Andheria A, Karanth K, Kumar N. 2007. Diet and prey profiles of three sympatric large carnivores in Bandipur Tiger Reserve, India. J Zool 273(2): 169-175.

Aragona M, Setz EZF. 2001. Diet of the maned wolf, Chrysocyon brachyurus (Mammalia: Canidae), during wet and dry seasons at Ibitipoca State Park, Brazil. J Zool, Lond 254: 131-136.

Arivazhagan C, Arumugam R, Thiyagesan K. 2007. Food habits of leopard (Panthera pardus fusca), dhole (Cuon alpines) and striped hyena (Hyaena hyaena) in a tropical dry thorn forest of southern India. J Bombay Nat Hist Soc 104: 178-187.

Aryal A, Panthi S, Barraclough RK, Bencini R, Adhikari B, Weihong J, Raubenheimer D. 2015. Habitat selection and feeding ecology of dhole (Cuon alpinus) in the Himalayas. J Mammal 96(1): 47-53.

Azlan JM, Sharma DSK. 2006. The diversity and activity patterns of wild felids in a secondary forest in peninsular Malaysia. Oryx 40: 36-41.

Bailey LL, MacKenzie DI, Nichols JD. 2013. Advances and applications of occupancy models. Methods in Ecology and Evolution. Online early view. Doi:10.1111/2041-210X.12100

Borah J, Deka K, Dookia S, Gupta RP. 2009. Food habits of dholes (Cuon alpinus) in Satpura Tiger Reserve, Madhya Pradesh, India. Mammalia 73: 85-88.

Brillouin L. 1956. Science and Information Theory. New York: Academic Press.

Buabudhara N. 2019. Green criminology approach on illegal wildlife hunting. Journal of Social Sciences Naresuan University 15 (2): 183 211. [Thai]
Bujne AE. 2000. Pollen analysis of faeces as a method of demonstrating seasonal variations in the diet of Svalbard reindeer (Rangifer tarandus platyrhynchus). Polar Res 19: 183-192.

Camardella AR, Abreu MF, Wang E. 2000. Marsupials found in felid scats in southern Brazil, and a range extension of Monodelphis theresa. Mammalia 64: 379-382.

Chame M. 2003. Terrestrial Mammal Feces: a morphometric summary and description. Mem Inst Oswaldo Cruz, Rio de Janeiro 98: 71-94.

Charaspet K, Sukmasuang R, Kheowsree N, Songsasen N, Simchareon S, Duengkae P. 2019. Some ecological aspects of dhole (Cuon alpinus) in the Huai Kha Khaeng Wildlife Sanctuary, Uthai Thani Province, Thailand. Folia Oecologica 46: 91-100.

Cohen JA. 1978. Cuon alpinus. Mamm Species 100: 1-3.

Corrêa CE, Albrecht MP, Hahn NS. 2011. Patterns of niche breadth and feeding overlap of the fish fauna in the seasonal Brazilian Pantanal, Cuiabá River basin. Neotropical Ichthyology. 9(3): 637-646.

Dalén L, Elmhagen B, Angerbjörn A. 2004. DNA analysis on fox faeces and competition induced niche shifts. Mol Ecol 13: 2389-2392.

Department of Forest Biology. 2013. Master Plan for Salak Pra Wildlife Sanctuary Management. Faculty of Forestry, Kasetsart University, Bangkok, Thailand. [Thai]

Department of Land Development. 2016. Land use map of Huai Kha Khaeng Wildlife Sanctuary. Ministry of Agriculture and Cooperatives. Bangkok. [Thai]

Durbin LS, Venkataraman A, Hedges S, Duckworth W. 2004. Dhole Cuon alpinus. In: SilleroZubiri C, Hoffmann M, Macdonald DW (eds) Status Survey and Conservation Action Plan Canids: Foxes, Wolves, Jackals and Dogs. IUCN/SSC Canid Specialist Group, Gland, Switzerland and Cambridge, UK.

Edgaonkar. 2008. Ecology of the Leopard Panthera pardus in Bori Wildlife Sanctuary and Satpura National Park, India. [Dissertation]. University of Florida, Miami, USA.

Fedriani JM, Fuller TK, Sauvajot RM, York EC. 2000. Competition and intraguild predation among three sympatric carnivores. Oecologia. 125: 258-270.

Floyd TJ, Mech LD, Jordan PJ. 1978. Relating wolf scat contents to prey consumed. J Wildl Mgmt 42: 528-532.

Forest Research Center. 1997. Application of Remote Sensing and GIS for Monitoring Forest Land Use Change in Huai Kha Khaeng Wildlife Sanctuary. Faculty of Forestry, Kasetsart University, Thailand. [Thai]

Fox M, Johnsingh AJT. 1975. Hunting and feeding in wild dogs. J Bombay Nat Hist Soc 72: 321-326.

Fragoso JMV, Huffman JM. 2000. Seed-dispersal and seedling recruitment patterns by the last Neotropical megafaunal element in Amazonia, the tapir. J Trop Ecol 16: 369-385.

Glen AS, Dickman CR. 2006. Diet of the spotted-tailed quoll (Dasyurus maculatus) in eastern Australia: effects of season, sex and size. J Zool 269: 241-248.

Grassman LI, Tewes ME, Silvy NJ, Kreetiyutanont KJ. 2005. Spatial ecology and diet of the dhole Cuon alpinus (Canidae, Carnivora) in north-central Thailand. Mammalia 69 (1): 11-20.

Gupta S, Mondal K, Sankar K, Qureshi Q. 2009. Estimation of striped hyena Hyaena hyaena population using camera traps in Sariska Tiger Reserve, Rajasthan, India. J Bombay Nat Hist Soc 106(3): 284-288.

Hayward MW, Henschel P, O'Brien J, Hofmeyr M, Balme GA, Kerley GIH. 2006. Prey preferences of the leopard (Panthera pardus). J Zool 270: 298-313. Doi: 10.1111/j.1469-7998.2006. 00139.x

Hayward MW, Jedrzejewski W, Jedrzejewska B. 2012. Prey preferences of the tiger Panthera tigris. J Zool 286: 221-231. Doi: 10.1111/j.1469-7998.2011. 00871.x

Hayward MW, Lyngdoh S, Habib B. 2014. Diet and prey preferences of dholes (Cuon alpinus): dietary competition within Asia's apex predator guild. J Zool 294(4): 255-266.

Hurlbert SH. 1978. The measurement of niche overlap and some relatives. Ecology 59: 66-77.

IUCN. 2020a. Dong Phayayen-Khao Yai Forest Complex. https://whc.unesco.org/en/list/590

IUCN. 2020b. Thungyai-Huai Kha Khaeng Wildlife Sanctuaries. https://whc.unesco.org/en/list/591/

Jacobs J. 1974. Quantitative measurement of food selection: a modification of the forage ratio and Ivlev's electivity index. Oecologia 14: 413-417.

Jacomo ATA, Silveira L, Diniz-Filho JAF. 2004. Niche separation between the maned wolf (Chrysocyon brachyurus), the crab-eating 
fox (Dusicyon thous) and the hoary fox (Dusicyon vetulus) in central Brazil. J Zool 262: 99-106.

Jenks KE, Chanteap P, Damrongchainarong P, Cutter P, Cutter P, Redford T, Lynam AJ, Howard JG, Leimgruber P. 2011. Using relative abundance indices from camera-trapping to test wildlife conservation hypotheses - an example from Khao Yai National Park, Thailand. Trop Conserv Sci 4(2): 113-131.

Jenks KE, Howard JG, Leimgruber P. 2012. Do ranger stations deter poaching activity in National Parks in Thailand? Biotropica 44: 826833.

Johnsingh AJT. 1992. Prey selection in three large sympatric carnivores in Bandipur. Mammalia 56(4): 517-526.

Johnsingh AJT. 1982. Reproductive and social behaviour of the Dhole, Cuon alpinus (Canidae). J Zool 198: 443-463.

Johnsingh AJT. 1983. Large mammalian prey-predators in Bandipur. J Bombay Nat Hist Soc 80:1-57.

Johnsingh AJT. 1985. Distribution and status of dhole Cuon alpinus Pallas, 1811 in South Asia. Mammalia 49: 203-208.

Kamler JF, Johnson A, Vongkhamheng C, Bousa AJ. 2012. The diet, prey selection, and activity of dholes (Cuon alpinus) in northern Laos. J Mammal 93(3):627-633.

Kamler JF, Songsasen N, Jenks K, Srivathsa A, Sheng L, Kunkel K. 2015 Cuon alpinus. The IUCN Red List of Threatened Species 2015 e.T5953A72477893. https://dx.doi.org/10.2305/IUCN.UK.20154.RLTS.T5953A72477893.en.

Kamler JF, Thatdokkham K, Rostro-García S, Bousa A, Caragiulo A, Crouthers R, Pay VIC, Pin C, Prum S, Vongkhamheng C, Johnson A Macdonald DW. 2020. Diet and Prey Selection of Dholes in Evergreen and Deciduous Forests of Southeast Asia. J Wildl Manag 84(7): 1396-1405.

Karanth KU, Nichols I JD. 1998. Estimation of tiger densities in India using photographic captures and recaptures. Ecology 79(8): 2852 2862 .

Karanth KU, Sunquist M. 1995. Prey selection by tiger, leopard, and dhole in tropical forests. J Anim Ecol. 64(4): 439-450.

Karssene Y, Chammem M, Khorchani T, Nouira S, Li F. 2017. Global warming drives changes in carnivore communities in the North Sahara Desert. Clim Res 72: 153-162.

Kauhala K, Auniola M. 2001. Diet of raccoon dogs in summer in the Finnish archipelago. Ecography. 24: 151-156.

Kawanishi K, Sunquist ME. 2008. Food habits and activity patterns of the Asiatic golden cat (Catopuma temminckii) and dhole (Cuon alpinus) in a primary rainforest of Peninsular Malaysia. Mammal Study 33(4): 173-177.

Kelly MJ, Holub EL. 2008. Camera trapping of carnivores: trap success among camera types and across species, and habitat selection by species, on Salt Pond Mountain, Giles Country, Virginia. North Eas Nat 15(2): 249-262. http://dx.doi.org/10.1656/1092-6194(2008)15 [249: CTOCTS]2.0.CO;2

Khoewsree N, Charaspet K, Sukmasuang R, Songsasen N, Pla-ard M, Thongbantum J, Kongchaloem W, Srinopawan K. 2020. Abundance, prey, and activity period of dholes (Cuon alpinus) in Khao Yai National Park, Thailand. Biodiversitas 21: 345-354

Kohn MH, York EC, Kamradt DA, Haught G, Sauvajot RM, Wayne RK. 1999. Estimating population size by genotyping faeces. R Soc 266 657-663

Koirala RK, Aryal A, Amiot C, Adhikiari B, Karmacharya D, Raubenheimer D. 2012. Genetic identification of carnivore scat: implication of dietary information for human-carnivore conflict in the Annapurna Conservation Area, Nepal. Zool Ecol 22:137-143.

Krebs CJ. 1989. Ecological Methodology. Harper Collins Publishers.

Lekagul B, McNeely JA. 1988. Mammals of Thailand. Darnsutha Press, Bangkok, Thailand.

Levins R.1968. Evolution in Changing Environments: Some Theoretical Explorations. Princeton University Press.

Lyra-Jorge MC, Ciocheti G, Pivello VR, Meirelles ST. 2008. Comparing methods for sampling large and medium sized mammals: camera traps and track plots. Eur J Wildl Res 54: 739-744. http://dx.doi.org/10.1007/s10344-008-0205-8

Mahmood T, Hussain I, Nadeem MS. 2011. Population estimate, habitat preference and the diet of small Indian mongoose (Herpestes javanicus) in Potohar Plateau, Pakistan. Pak J Zool 43(1): 103-111.

Marshall-Pescini S, Kaminski J. 2014. The Social dog: history and evolution. In: The Social Dog: Behavior and Cognition. Kaminski J, Marshall-Pescini S (eds) Academic Press is an imprint of Elsevier.
https://www.amazon.com/Social-Dog-BehaviorCognition/dp/0124078184

NPRD (National Parks Research and Innovation Development Center). 2017. Attitudes and Opinions of Thai Tourists towards the Conservation of Crocodiles in Khao Yai National Park. National Parks Wildlife and Plant Conservation Department, Nakorn Ratchasima Province, Thailand. [Thai]

Novakowski GC; Hahn NS, Fugi R. 2008. Diet seasonality and food overlap of the fish assemblage in a Pantanal pond. Neotrop Ichthyol 6(4): $567-576$.

O’Brien TG, Kinnaird MF, Wibisono HT. 2003. Crouching tigers, hidden prey: Sumatran tiger and prey populations in a tropical forest landscape. Anim Conserv 6: 131-139.

O'Brien TG. 2008. On the use of automated cameras to estimate species richness for large-and medium-sized rainforest mammals. Anim Conserv 11: 179-181. http://dx.doi.org/10.1111/j.1469 1795.2008.00178.x

Page LK, Swihart RK, Kazacos KR. 2001. Seed preferences and foraging by granivores at raccoon latrines in the transmission dynamics of raccoon roundworm (Baylisascaris procyonis). Can J Zool 79: 616622

Phetdee. 2000. Food Habits of the Tiger (Pantera tigris Linnaeus) in Huai Kha Khaeng Wildlife Sanctuary by Fecal Analysis. [Dissertation]. Kasetsart University, Bangkok. [Thai]

Pianka ER. 1973. The structure of lizard communities. Annu Rev Ecol Evol Syst 4: 53-74.

Prater SH. 1971. The Book of Indian Animals. Bombay Natural History Society, Oxford University Press, United Kingdom.

Prayoon. 2014. Abundance, suitable habitat, and main preys of Dhole (Cuon alpinus (Pallas, 1811) in Thap Lan National Park. [Dissertation]. Kasetsart of University. [Thai]

Palmer MS, Swanson A, Kosmala M, Arnold T, Packer C. 2018. Evaluating relative abundance indices for terrestrial herbivores from large-scale camera trap surveys. Afr J Ecol 56: 791-803. Doi: 10.1111/aje. 12566

Ramesh. 2010. Prey Selection and Food Habits of Large Carnivores: Tiger Panthera tigris, Leopard Panthera pardus and Dhole Cuon alpinus in Mudumalai Tiger Reserve, Tamil Nadu. [Dissertation]. Saurashtra University, Gujarat, India.

Ramesh T, Kalle R, Sankar K, Qureshi QJMS. 2012. Dietary partitioning in sympatric large carnivores in a tropical forest of Western Ghats, India. Mammal Study 37(4):313-321.

Ray JC, Sunquist ME. 2001. Trophic relations in a community of African rainforest carnivores. Oecologia (Berlin) 127:395-408

Ripple WJ, Estes JA, Beschta RL, Wilmers CC, Ritchie EG, Hebblewhite M, Berger J, Elmhagen B, Letnic M, Nelson MP, Schmitz OJ, Smith DW, Wallach AD, Wirsing AJ. 2014. Status and Ecological Effects of the World's Largest Carnivores. Science 343(6167):1241484. Doi: 10.1126/science. 1241484

Rovero, F, Tobler M, Sanderson J. 2010. Camera trapping for inventorying terrestrial vertebrates. In: Jutta Eymann JD, Häuser C, Monje JC, Samyn Y, Spiegel DVD (eds) Manual On Field Recording Techniques and Protocols for All Taxa Biodiversity Inventories. Belgium Focal Point to the GTI, Brussels, Belgium.

Rovero F, Martin E, Rosa M, Ahumada JA, Spitale D. 2014. Estimating species richness and modelling habitat preferences of tropical forest mammals from camera trap data. PLOS ONE. 9(10): e110971. https://journals.plos.org/plosone/article?id=10.1371/journal.pone.010 3300

Santos MDFM, Hartz SM. 1999. The food habits of Procyon cancrivorus (Carnivora, Procyonidae) in the Lami Biological Reserve, Porto Alegre, Southern Brazil. Mammalia 63(4): 525-530.

Sanz JL, Köchling T. 2007. Molecular biology techniques used in wastewater treatment: an overview. Proc Biochem 42: 119-133.

Schaller GB. 1977. Mountain Monarchs: Wild Sheep and Goats of the Himalayas. The University of Chicago Press, Chicago, Illinois.

Segurado P, Santos JM, Pont D, Melcher AH, Jalon DG, Hughes RM, Ferreira MT. 2011. Estimating species tolerance to human perturbation: Expert judgment versus empirical approaches. Ecological Indicators 11(6): 1623-1635.

Selvan KM, Veeraswami GG, Hussain SA. 2013. Dietary preference of the Asiatic wild dog (Cuon alpinus). Mamm Biol 78: 486-489.

Seton ET .1925. On the study of scatology. J Mammal 6: 47-49.

Shrestha TK. 1997. Mammals of Nepal. B. Shrestha and R. K. Printers, Teku, Kathmandu, Nepal. 
Silver SC, Ostro LET, Marsh LK, Maffei L, Noss AJ, Kelly MJ, Wallace RB, Gómez H, Ayala G. 2004. The use of camera traps for estimating jaguar Panthera onca abundance and density using capture/recapture analysis. Oryx 38(2): 148-154.

Simcharoen, S. 2008. Ecology of the Leopard (Panthera Pardus Linn.) in Huai Kha Khaeng Wildlife Sanctuary. [Dissertation]. Kasetsart University, Bangkok, Thailand.

Siripattaranukul K, Paglia S, Sukmasuang R, Horradee S. 2015. The species diversity and abundance of wild animals in Chalerm Rattanakosin National Park, By camera trapping. Journal of Wildlife in Thailand 22(1): 91-100. (Thai)

Slangsingha N, Duengkae P, Kumsuk M, Nittaya K. 2007. Diet of Asian wild $\operatorname{dog}$ (Cuon alpinus) in Phu Khieo Wildlife Sanctuary, Chaiyaphum Province; Thailand. Journal of Wildlife in Thailand 14(1): 54-64 (Thai)

Slangsingha. 2012. Prey Species and Habitat Used of Dhole (Cuon alpinus) in Phu Khieo Wildlife Sanctuary, Chaiyaphum Province. [Dissertation]. Kasetsart University, Bangkok, Thailand.

Srivathsa A, Karanth KK, Jathanna D, Kumar NS, Karanth KU. 2014. On a Dhole Trail: Examining Ecological and Anthropogenic Correlates of Dhole Habitat Occupancy in the Western Ghats of India. PLOS ONE 9(6): e98803. https://doi.org/10.1371/journal.pone.0098803

Srivathsa A, Sharma S, Singh P, Punjabi GA, Oli MK. 2020. A strategic road map for conserving the endangered dhole Cuon alpinus in India. Mammal Review. Doi: 10.1111/mam.12209.

Sunquist ME, Sunquist FC. 1999. Ecological constraints on predation by large felids. In: Seidensticker J, Christie S. Jackson P. (eds) Riding the Tiger: Tiger Conservation in Human-Dominated Landscapes. London: Zoological Society of London and Cambridge University Press.

The Western Forest Complex Ecosystem Management Project. 2003. The Vegetation and the Flora of the Western Forest Complex: Using Rapid Ecological Assessment and Vegetation Description in the WEFCOM Area. Wildlife and Plant Conservation Department, Bangkok.

Thinley P, Kamler JF, Wang SW, Lham K, Stenkewitz U, Macdonald D. 2011. Seasonal diet of dholes (Cuon alpinus) in north-western Bhutan. Mamm Biol 76(4): 518-520.

Tobler MW, Carrilo-Percastegui SE, Pitman RL, Mares R, Powell G. 2008. An evaluation of camera traps for inventorying large-andmedium-sized terrestrial rainforest mammals. Anim Conserv 11: 169178. http://dx.doi.org/10.1111/j.1469-1795.2008.00169.x

Trolle M, KERY M. 2003. Camera-trap study of ocelot and other secretive mammals in the northern Pantanal. Mammalia
69(3-4): 405-412.

Tucker MA, Rogers TL. 2014. Examining predator-prey body size, trophic level and body mass across marine and terrestrial mammals. Proc Royal Soc B 281: 20142103. http://dx.doi.org/10.1098/rspb.2014.2103

Van Valkenburgh BJP. 1991. Iterative evolution of hypercarnivory in canids (Mammalia: Carnivora): evolutionary interactions among sympatric predators. Paleobiology 17(4):340-362.

Voigt W, Perner J, Davis AJ, Eggers T, Schumacher J, Bahrmann R. 2003. Trophic levels are differentially sensitive to climate. Ecology 84: 2444-2453.

Voss RS, Emmons LH. 1996. Mammalian diversity in Neotropical Lowland Rainforests: a preliminary assessment. Bull Am Mus Nat Hist 230: 1-115.

Wang. 2008. Understanding ecological interactions among carnivores, ungulates and farmers in Bhutan's Jigme Singye Wangchuck National Park. [Dissertation]. Cornell University, Ithaca, NY, USA.

Wang S, Macdonald DJJ. 2009. Feeding habits and niche partitioning in a predator guild composed of tigers, leopards and dholes in a temperate ecosystem in central Bhutan. J Zool 277(4): 275-283.

Weaver JL. 1993. Refining the equation for interpreting prey occurrence in grey wolf scats. J Wildl Manage 57: 534-538.

Webbon CC, Baker PJ, Harris S. 2004. Faecal density counts for monitoring changes in red fox numbers in rural Britain. J Appl Ecol 41: 768-779.

Western Forest Complex. 2004. GIS Database and its Applications for Ecosystem Management. The Western Forest Complex Ecosystem Management Project, Department of National Park, Wildlife, and Plant Conservation, Bangkok, Thailand.

Williams PA, Karl BJ, Bannister P, Lee WG. 2000. Small mammals as potential seed disperse in New Zealand. Austral Ecol 25: 523-532.

Winemiller KO, Pianka ER. 1990. Organization in natural assemblages of desert lizards and tropical fishes. Ecological Monographs 60(1): 2755 .

Wolf C, Ripple WJ. 2016. Prey depletion as a threat to the world's large carnivores. R Soc Open Sci 3:3(8):160252. https://doi.org/10.1098/rsos.160252

Wolf C, Ripple WJ. 2017. Range contractions of the world's large carnivores. R Soc Open Sci 4: 170052. DOI: 0.1098/rsos.170052

Zaragozí B, Belda A, Giménez P, Navarro JT, Bonet A. 2015. Advances in integration with GIS. Ecol Inform 30: 6-11. 